ROCZNIKI HUMANISTYCZNE

Tom LXIX, zeszyt 11 - 2021

ZESZYT SPECJALNY/SPECIAL ISSUE

DOI: https://doi.org/10.18290/rh216911-3s

\title{
IN SEARCH OF A MODEL FOR THE DERIVATION OF DISPOSITIONAL AND PASSIVE POTENTIAL ADJECTIVES BASED ON PARTICIPLES IN IRISH
}

\begin{abstract}
This paper tests the explanatory potential of two competing separationist models, a lexicalist LMBM model and a constructionist DM model, in the analysis of overtly marked dispositional and passive potential adjectives based on participles in Irish. In LMBM, which upholds a strict division between lexical and morphosyntactic phenomena, Irish adjectives must be derived directly from the verbal root or a special allomorphic variant of the verbal root which is used in the context of adjectivising morphology. The first solution involves the multiplication of formal markers, the latter misses the formal and semantic relationship between the supposedly "special" verbal stem and the participle. DM fares better since there is no theoretical ban on the use of participles as bases for adjectives and the presence of participles in the structure of Irish adjectives is corroborated by distributional facts. The proposed structures form a continuum from verbal participles via adjectivised participles to deverbal adjectives.
\end{abstract}

Keywords: inherent inflection; departicipial adjective; dispositional adjective; passive potential adjective; LMBM; Distributed Morphology; Irish.

\section{INTRODUCTION}

The aim of this paper is to analyse the derivation of two kinds of eventive adjectives in Irish against the broader linguistic debate concerning the role of morphology in the architecture of grammar, as viewed by lexicalist and constructionist theories. ${ }^{1}$

Maria Bloch-Trojnar, PhD, Dr. Litt., The John Paul II Catholic University of Lublin, Faculty of Humanities, Institute of Linguistics, Department of Celtic Studies; e-mail: bloch@kul.pl; ORCID: https://orcid.org/0000-0003-2340-2128. 
The lexicalist strain of research is represented here by the Lexeme Morpheme Base Morphology (LMBM) model put forward by Robert Beard and the syntax-oriented perspective by the Distributed Morphology (DM) model first proposed by Morris Halle and Alec Marantz. The two models have been selected for discussion, because-although they both envisage postsyntactic spell-out - they belong to completely different research programmes. The fundamental difference between them is whether they envisage a separate grammatical module responsible for word structure. LMBM is lexeme based and recognises the existence of a categorial morphological component in the Lexicon, whereas DM is morpheme-based and views syntax as the sole generative engine.

Evidence from various languages demonstrating that inherent inflection can feed derivation (Booij; Chapman; Rainer; Cetnarowska, "On Inherent Inflection") poses a problem for those lexicalist approaches which opt for the inflection-derivation dichotomy. In cases of participle-to-adjective conversion, which is fairly common cross-linguistically, ${ }^{2}$ various theories fare more or less evenly (Cetnarowska, "Departicipial Adjectives"). However, an analysis of cases where participles act as the base for further overt category-changing affixation $^{3}$ seems to favour the approach which maximises the formal similarity between morphology and syntax, since it has the advantage of being able to naturally explain this phenomenon. Dispositional and passive potential adjectives in Irish are an instance of such overtly marked departicipial adjectives. Since linguistic theories should be evaluated in accordance with their descriptive and explanatory potential, Irish deverbal adjectives will serve as a useful testing ground for competing theoretical explanations. To bring the puzzle into focus, section 2 will provide more detailed information concerning their morphological make-up. Section 3 will present the basic tenets of LMBM, the

\footnotetext{
${ }^{1}$ The term "constructionist" is used in this paper as a synonym for what some researchers label "neo-constructional," as opposed to the "traditional" constructional approach of Goldberg, Jackendoff and Ruppenhofer and Michaelis.

${ }^{2}$ Participle-to-adjective conversion has been evoked, e.g. in English (Bresnan; Levin and Rappaport), German (Wunderlich), Dutch (Hoekstra), Greek (Markantonatou), Hungarian (Laczkó) and Polish (Cetnarowska, "On Inherent Inflection"). The status and representation of participles and their corresponding adjectives has been of interest since Wasow, giving rise to competing constructionist (e.g. Anagnostopoulou; Embick; Alexiadou and Anagnostopoulou; Alexiadou et al., "The Argument Structure") and lexicalist accounts (e.g. Levin and Rappaport; Sleeman and Verheugd).

${ }^{3}$ Such cases are far less common cross-linguistically. For a discussion of cases where passive potential adjectives are not only semantically, but also formally linked with the passive participle see, e.g. Oltra-Massuet and the references therein concerning data from Georgian, Turkish and Hungarian, Cinque for an analysis of -bile in Italian, Leuman et al. for Latin data, and Sullivan for Nahuatl.
} 
handling of departicipial adjectives in this model, along with the problems that it faces in accommodating the Irish data and possible solutions within its limits. By the same token, in section 4 we will present the DM perspective on departicipial adjectives in general and on departicipial adjectives in Irish in particular. Our evaluation of both approaches in handling the Irish data will be summarised in section 5 .

\section{THE IRISH DATA}

\subsection{Non-finite verb forms in Irish}

Traditional Irish grammars distinguish two non-finite forms: the verbal noun (VN) and the verbal adjective (VA) (de Bhaldraithe; Ó hAnluain). The verbal noun, in addition to numerous other functions, acts as the infinitive in modal constructions ( $1 \mathrm{a}$ ) and the participle in progressive structures (1b). The identification of these categories is possible on the basis of their distributional and morphological characteristics (Bloch-Trojnar, Polyfunctionality 59-114). ${ }^{4}$

(1)
Caithfidh sé beoir
a ól.
Infinitive
a. must he beer.ACC
'He has to drink beer.'
Bhí sé ag ól beorach.
'He was drinking beer.'
b. was he PRT drink.VN beer.GEN

The verbal adjective (VA), which is marked with the suffix -ta/te or -tha/the, functions as the perfective participle in passive perfective and resultative constructions (Ó Sé, "The 'After' Perfect" 197; Doyle, "Morphosyntactic Change" 144-46):

\footnotetext{
${ }^{4} \mathrm{VNs}$ in modal constructions, as in (1a), are regarded as infinitives, because they are preceded by the leniting particle $a$ and the object noun in the accusative case. VNs in the progressive construction, as in (1b), are interpreted as the present/progressive participle because they are preceded by the particle ag and followed by the object in the genitive case (McCloskey, "VP"; Doyle, Covert and Overt Pronominals; Bloch-Trojnar, Polyfunctionality; Carnie).
} 
(2) Tá an bheoir ólta.

\section{Perfective participle}

is the beer drink.PPRT

(Verbal Adjective)

'The beer has been drunk.'

The formation of the perfective participle is fairly regular and can be predicted from the phonological properties and conjugation class features of the base verb. ${ }^{5}$ The participle can also act as a nominal modifier, e.g. pláta briste 'broken plate', fuinneog oscailte 'open window', pósadh measctha 'mixed marriage'. ${ }^{6}$

Notably, the verbal adjective/perfective participle is homonymous with a positional variant of the present participle in the nominal post-modifier position. We advance this position counter to traditional grammars, which in this context speak of the genitive case of the VN (Bloch-Trojnar, Polyfunctionality $80-90)^{7}$
lucht ólta
beorach
people drink.PROG.PRT beer.GEN
'beer drinkers, lit. people drinking beer'

Progressive participle

${ }^{5}$ For a detailed account and lists of exceptions see de Bhaldraithe and Ó hAnluain.

${ }^{6}$ Adjectives in Irish follow the head noun they modify, e.g. pláta beag 'a small plate'.

${ }^{7}$ The so-called "genitive of VN" cannot be regarded as a bona fide case ending because it shares a number of traits with non-finite forms to the exclusion of nominal characteristics. Firstly, its formation is conditioned by the properties of the verbal base, in that, just as with the perfective participle, it is conditioned by the conjugation class marking of the verbal stem. Case endings cannot depend on conjugation class marking. Secondly, the form in (3) is followed by an object NP like the verb in a corresponding clause and the object is in the genitive case, which is typical of verbs in the progressive (cf. (1b) above). Thirdly, the structure with a supposed VN.GEN is equivalent to an infinitive construction:

(i)

$\begin{array}{lllll}\text { lucht ólta } & \text { beorach } & \text { lucht beoir } a \text { ól } \\ \text { people drink.VN.GEN beer.GEN } & \text { people beer.ACC } & \text { PRT drink.VN } \\ \text { 'beer drinkers' } & & \text { 'beer drinkers' } & \end{array}$

In addition to this, the structure in (3) does not conform to the pattern in which a noun is postmodified by two other NPs. If we adopt the traditional approach, in (i) above the noun is followed by a sequence of two nouns in the genitive case. However, when a noun in Irish is modified by two other nouns, the first is in the common form and the second is in the genitive case, as in (ii) below:

(ii) cóta mhac Sheáin

Sean.GEN

'Sean's son's coat' 
The formal difference between the two categories manifests itself only in the case of -áil VNs, such as pábháil 'pave.vN', in which the perfective participle takes the regular -te ending (4a), whereas the positional variant of the present participle is marked with the depalatalising $-a$ suffix (4b):

(4) a. Tá an tsráid pábháilte.

is the street pave.PPRT

'The street has been paved.'

b. fear pábhála sráide

man pave.PROG.PRT street.GEN.SG

'street paver'

\section{Perfective participle}

Progressive participle

Since VNs can act not only as non-finite verb forms, but also as nominalisations displaying the action-result polysemy,${ }^{8}$ the postnominal progressive participle is also distinct from the genitive case of the $\mathrm{VN}$ in its strictly nominal function. Many VNs are listed in dictionaries with two genitives: one following one of the five declension patterns available for Irish, and another identical to the PPRT. Such is the case with, for example, $o l$, whose dictionary entry reads 'ól-gen.sg. as substantive óil, as vn ólta' (Ó Dónaill 928). Consider the examples in (5) below:

(5)

$$
\begin{aligned}
& \text { a. amhrán óil } \\
& \text { song drink.NMLZ.GEN } \\
& \text { 'drinking-song' }
\end{aligned}
$$

b.

$\begin{array}{lll}\text { lucht ólta } & \text { beorach } & \text { Postnominal progressive } \\ \text { people drink.PROG.PRT } & \text { beer.GEN } & \text { participle } \\ \text { 'beer drinkers' } & & \end{array}$

\section{Nominal genitive}

For most VNs, however, there is only one genitive form available and it is homonymous with the perfective participle. This applies to VNs taking the most productive markers, i.e. -(e)adh (6a), the vowel - $\dot{u}$ (6b), $-t$ which follows sonorant consonants [ $1 \mathrm{r} \mathrm{n} \mathrm{p}]$ (6c), or to VNs ending in some other vowel (6d).

\footnotetext{
${ }^{8}$ The VN $o ́ l$ in its strictly nominal function will be interpreted either as 'act(ion) of drinking' or 'a drink', in which case it will take the 1 st declension genitive marker, i.e. the palatalisation of the final consonant (óil).
} 
(6)

\begin{tabular}{|c|c|c|c|}
\hline Verb, VN & $\begin{array}{l}\text { Perfective } \\
\text { PRT }\end{array}$ & $\begin{array}{l}\text { Postnominal } \\
\text { Progressive PRT }\end{array}$ & $\begin{array}{l}\text { Nominal } \\
\text { genitive }\end{array}$ \\
\hline mol, moladh 'praise' & molta & molta & molta \\
\hline buail, bualadh 'hit, strike' & buailte & buailte & buailte \\
\hline ceartaigh, ceartú 'correct' & ceartaithe & ceartaithe & ceartaithe \\
\hline athraigh, athrú 'change' & athraithe & athraithe & athraithe \\
\hline oscail, oscailt 'open' & oscailte & oscailte & oscailte \\
\hline labhair, labhairt 'speak' & labhartha & labhartha & labhartha \\
\hline súigh, sú 'absorb' & súite & súite & súite \\
\hline treáigh, treá 'pierce' & treáite & treáite & treáite \\
\hline
\end{tabular}

Thus, despite prevalent surface homonymy (7a), what traditional grammars call the genitive case of the $\mathrm{VN}$ and what we regard as the positional variant of the progressive participle is categorially distinct from the perfective participle (7b) and the nominal genitive (7c).

(7)

$\begin{array}{ll}\text { Verb, VN } & \text { Perfective } \\ & \text { PRT }\end{array}$
a. mol, moladh 'praise'
molta
b. pábháil, pábháil 'pave' pábháilte
c. ól, ól 'drink'

\section{Postnominal Progressive PRT}

molta

pábhála

ólta
Nominal genitive

molta

pábhála

óil

In what follows, we shall refer to the postnominal variant of the active/progressive participle as ProgPRT.

\subsection{The formation of passive potential adjectives (PPAs) in Irish}

Deverbal adjectives expressing the concept of "passive possibility" in Irish bear the distinctive prefixes $s o$ - and $i n$-added to the perfective participle, ${ }^{9}$ e.g.

\footnotetext{
${ }^{9}$ Both prefixes are productive. However, it is not possible to disjunctively specify their domains, which frequently results in the formation of doublets (cf. (8b) and (8c)). Both affixes select transitive verbs, but the semantic restrictions can only be expressed in terms of tendencies. The prefix so- shows
} 
(8)
a. mol 'praise'
b. léigh 'read'
c. glac 'take, accept'
d. aistrigh 'move, translate'

Verb

\section{PPRT Passive potential adjective (PPA)}

molta inmholta 'commendable, praiseworthy'

léite soléite/inléite 'readable'

glactha inghlactha/so-ghlactha 'acceptable'

aistrithe inaistrithe 'movable, translatable'

In formal terms, the make-up of potential adjectives follows straightforwardly if we take the perfective participle as the base. This position is taken in the vast majority of sources, including de Bhaldraithe, Ó Dónaill and Ó hAnluain. The only source suggesting that "we seem to be dealing with simultaneous prefixation and suffixation" in the formation of potential adjectives is Doyle (Irish 60). The perfective participle is the most natural base for passive potential adjectives because there is no prefixal-suffixal derivation or circumfixation in Irish. It is also worth noting that in cases where the past participle contains a suppletive root or an allomorphic variant, this suppletive participle form is selected as the base rather than the root, as shown in (9) below:

(9)

$\begin{array}{lll}\begin{array}{l}\text { Verb } \\ \text { abair 'say, speak' }\end{array} & \begin{array}{l}\text { PPRT } \\ \text { ráite }\end{array} & \begin{array}{l}\text { PPA } \\ \text { inráite 'fit to be said, mentionable, } \\ \text { expressible, pronounceable' }\end{array} \\ \text { ith 'eat' } & \text { ite } & \text { inite 'edible' } \\ \text { cuir 'sow, plant' } & \text { curtha } & \text { inchurtha 'sowable, tillable' }\end{array}$

\subsection{The formation of potential adjectives in Irish}

Dispositional/potential adjectives in Irish bear the suffix -ach and show active semantics, i.e. 'such that Vs, such that can V, such that is inclined to V'. According to Bloch-Trojnar ("Peripheral"), the base for this process is the positional variant of the active participle used to post-modify nouns, which usually is homonymous with the perfective participle (cf. (6) above):

\footnotetext{
a preference for verbs of motion, while the prefix in- for verbs of measure, transfer of possession, judgement verbs and Subject Experiencer verbs. For a detailed analysis of this category, the reader is referred to Bloch-Trojnar ("Constraints," "Corpus-Based Perspective").
} 
(10)

Verb
mol 'praise'
súigh 'absorb'
ceartaigh 'correct,
amend'
labhair 'speak'

\section{ProgPRT Potential adjective}

molta moltach 'laudatory, approving'

súite súiteach 'absorbent'

ceartaithe ceartaitheach 'corrective, amending'

labhartha labharthach 'talkative, vociferous, noisy'

\subsection{Deverbal adjectives in Irish in relation to non-finite forms}

Despite surface homonymy, two different categories act as bases in the formation of deverbal adjectives in Irish. Dispositional adjectives are related to the progressive participle, whereas passive potential adjectives to the perfective participle. This claim can be supported on semantic and formal grounds.

There is a systematic semantic difference between the adjectives in -ach, which show active semantics and the adjectives prefixed with so- and in-, which show passive semantics. Consider some examples in (11):

Verb, ProgPRT =
PPRT
mol, molta
'praise'
roinn, roinnte
'divide'
athraigh, athraithe
'change, move'
basc, basctha
'bash, crush'
minigh, minithe
'smooth, explain'
gluais, gluaiste
'move'

Potential adjective

moltach

'laudatory'

roinnteach

'distributive'

athraitheach

'changeable, variant'

bascthach

'crushing, severe'

minitheach

'explanatory'

gluaisteach

'mobile, motile'

\section{Passive potential adjective}

inmholta

'commendable, praiseworthy'

soroinnte/inroinnte

'divisible'

so-athraithe

'easy to change, adjustable'

so-bhasctha

'easily injured'

somhinithe

'easily explained'

soghluaiste

'movable, mobile'

In addition to this, in cases where the form of the PPRT and that of the ProgPRT differ, the former acts as the base for passive adjectives and the latter 
for dispositional ones. This applies to verbs in -áil, ${ }^{10}$ whose perfective participle is regularly formed with the -te suffix, whereas the depalatalising $-a$ ending is found on the postnominal variant of the progressive participle, as in (4a) and (4b) above. The passive potential adjectives related to verbs in -áil show a formal affinity to the perfective participle, e.g. pléasáil, pléasáilte 'please, please.PPRT' — soi-phléasáilte 'such that can be pleased' (de Bhaldraithe 243). More such forms can be found in the New English-Irish Dictionary: ${ }^{11}$

(12)

$$
\begin{aligned}
& \text { Verb, PPRT } \\
& \text { cóireáil, cóireáilte 'treat' } \\
& \text { priontáil, priontáilte 'print' } \\
& \text { cliceáil, cliceáilte 'click' } \\
& \text { glasáil, glasáilte 'lock' } \\
& \text { tástáil, tástáilte 'test' }
\end{aligned}
$$

\author{
Passive potential adjective \\ galair inchóireáilte 'treatable diseases' \\ inphriontáilte 'printable' \\ inchliceáilte 'clickable' \\ inghlasáilte 'lockable' \\ intástáilte 'testable'
}

The formation of active potential adjectives involves the selection of the ProgPRT as the base, which is the same as the nominal genitive terminating in $-a$, as depicted in (13) below:

(13)
Verb, ProgPRT
sóinseáil, sóinseála 'change'
tuairteáil, tuairteála 'pound, thump, buffet'
sábháil, sábhála 'save, rescue, deliver'
diobháil, diobhála 'injure, harm'
tarrtháil, tarrthála 'rescue, save, deliver'
spáráil, spárála 'spare’

\author{
Active potential adjective \\ sóinseálach 'changeable, variable' \\ tuairteálach 'pounding, buffeting' \\ sábhálach 'saving, sparing, thrifty' \\ diobhálach 'injurious, harmful' \\ tarrthálach 'rescuing, saving, helpful' \\ spárálach 'sparing, frugal'
}

\footnotetext{
${ }^{10}$ The suffix -ál is a productive marker of denominal verbs (e.g. burla 'bundle'-burláil 'to bundle') and a regular means of adapting English roots (e.g. drive-draibheáil) (Wigger 207-10; Doyle, Noun Derivation 99).

${ }^{11}$ The examples in (12) and (13) are quoted from Bloch-Trojnar ("Peripheral” 36).
} 
The example in (14) provides further evidence that the two different participle categories act as bases in deverbal adjective formation.

\begin{tabular}{|c|c|c|}
\hline $\begin{array}{l}\text { Verb, ProgPRT, } \\
\text { PPRT }\end{array}$ & Active adjective & $\begin{array}{l}\text { Passive potential } \\
\text { adjective }\end{array}$ \\
\hline tuig, tuisceana, tuighte & tuisceanach & intuigthe, sothuigthe \\
\hline 'understand' & 'understanding, considerate' & 'understandable' \\
\hline
\end{tabular}

Formal and semantic differences between active potential adjectives and passive potential adjectives lead us to the conclusion that the former are best described as being related to the ProgPRT, whereas the latter to the PPRT. We will now test two theoretical models with respect to their capacity to account for these linguistic facts.

\section{AN LMBM PERSPECTIVE}

This section will present the most important characteristics of the LMBM model (3.1), its treatment of deverbal adjectives (3.2) and the problems that it faces in providing a comprehensive account of the Irish data (3.3), which will lead us to the conclusion that an alternative account is necessary (3.4).

\subsection{The basic tenets of LMBM}

In contradistinction to DM, LMBM is lexeme-based, which means that lexemes (roots/stems) specified for lexical category are listed in the lexicon. In this model, lexical and syntactic rules are viewed as abstract operations which apply to the grammatical representation of a lexeme, whereas the formal operations which realise these abstract feature matrices (affixation, prosodic variation, internal modification, $\varnothing$, etc.) are post-syntactic, and take place in an autonomous Morphological Spelling Component (MS-Component). Thus, LMBM, like Halle and Marantz's (“Some Key Features") Distributed Morphology, endorses separationism.

LMBM adheres to Perlmutter's Split Morphology Hypothesis (95) with the proviso that the split is restricted to the abstract grammatical level. ${ }^{12}$ Derivation and inflection, termed L-derivation and I-derivation respectively,

\footnotetext{
${ }^{12}$ According to Perlmutter, morphosyntactic features originate in syntax, whereas word formation processes operate in the lexicon.
} 
are distinct aspects of morphology which operate on two kinds of grammatical functions $g: g_{L}$, inherent (morpho)lexical categories interior to the word in the lexicon, and $g_{I}$, (morpho)syntactic inflectional categories in the phrase structure. ${ }^{13}$ Morphological spell-out builds outwards starting from the modification of the phonological base in response to each feature or set of features that serve as conditions on its operations. The inflectional features of the terminal node are expressed following the realisation of all lexical features.

\subsection{Departicipial and deverbal adjectives in LMBM}

Beard $(196,321)$ regards active adjectives as distinct from participles, and at the same time views both of them as derived from verbal bases. He observes that the formal overlap between the active adjective, also referred to as the subjective/agentive qualitative adjective, and the active participle is only partial. Namely, the suffix -ing is the only marker of the syntactically formed participle, whereas the lexically derived adjective is additionally marked with -ive, -ant and -ary. The two categories are kept distinct on account of different morphological and syntactic characteristics, ${ }^{14}$ some of which are shown in (15) below:

(15)

$\begin{array}{cl}\text { Affixes } & \text { Subjective Adjective } \\ & \text { is (very/un)surpris-ing } \\ \text { Same } & \text { is (very/un)excit-ing } \\ & \text { is (very/un)mov-ing } \\ & \text { is (very/un)product-ive } \\ \text { Distinct } & \text { is (very/un)repent-ant } \\ & \text { is (very/un)compliment-ary }\end{array}$

\section{Active Participle}

(not) surpris-ing (very much)

(not) excit-ing (very much)

(not) mov-ing (very much)

(not) produc-ing (very much)

(not) repent-ing (very much)

(not) compliment-ing (very much)

${ }^{13}$ For example, in the verbal domain Verb Class and Transitivity are morpholexical features of lexical items, whereas Modality, Mood, Aspect, Voice, Tense, Person, and Agreement are morphosyntactic.

${ }^{14}$ Adjectives can be prefixed with un-, whereas participles express the negative by means of not. An -ing form is an adjective if it can be turned into an adverb by the addition of -ly (e.g. surprisingly) and if it can be preceded by a degree adverb, such as very, so, too. These intensifiers are incompatible with participles which require very much or a lot. Active adjectives (unlike participles) are not confined to the predicative position and can be used attributively, as in: a (very/un)surprising result, a (very/un)moving story. 
By the same token, passive participles, despite formal identity, should be kept distinct from Objective qualitative adjectives (Beard 321): ${ }^{15}$

\author{
Objective Adjective \\ is (very/un) surprise-ed \\ is (very/un) mov-ed \\ is (very/un) bent \\ is (very/un) swoll-en
}

\author{
Participle \\ (*very/not) surprise-ed (very much) \\ (*very/not) mov-ed (very much) \\ (*very/not) bent (very much) \\ (*very/not) swoll-en (very much)
}

In the LMBM model, the formal identity of the adjective and the present/past participle does not mean that one is derived from the other. Each of them may be regarded as related to the verbal root by a lexical and a syntactic operation respectively, which happen to be spelled out by the same formal exponent (or morphomic function in the sense presented by Aronoff). Since deverbal adjectives may inherit two-place predicates from their base verbs, as in e.g. ANNOY (XY), but are themselves one-place predicates in symbolic logic, they may logically link with only one of the two arguments of the base. One form of adjective assigns the first (Subject) argument of the base verb to its head noun (the annoying boy), and another assigns the second (Object) (the annoyed boy). This explains why there are two transpositional classes of deverbal adjectives, i.e. Subjective/Agentive qualitative adjectives and Objective/Patientive qualitative adjectives. The derivation of passive potential adjectives in -able (e.g. breakable, manageable, understandable) is accomplished in this framework by an abstract functional L-derivation rule in which the concepts of Object and Potentiality are involved (see also Szymanek). Since morphological spell-out is divorced from the abstract semantico-syntactic effects of the rule, there is no expectation of passive potential semantics being reflected in the morphological shape of the derivative.

\subsection{Problems for LMBM in the handling of the Irish data}

In section 2 , we concluded that the surface forms of deverbal adjectives in Irish are best accounted for by adding affixes to participle forms, whose

\footnotetext{
${ }^{15}$ Adjectives in -ed/-en can be used attributively in prenominal positions (a heated argument, a married man, the destroyed building), can be modified by very (his very reduced circumstances), can serve as derivational bases to which the suffix -ly or the prefix un-is attached (heatedly, an unwoven rug, the uncrushed resistance) or show stative resultative semantics (The keeper's hand was severely bitten) (see e.g. Bauer, English Word Formation; Borer, "V+ing"; Adams).
} 
allomorphic variants are predictable from verb class features. However, in line with LMBM principles, the root, and not the participial form, should act as the base, since the spell-out of morpholexical features precedes the spell-out of morphosyntactic ones. In order to salvage the inflection-derivation split, three solutions present themselves in this model: to reanalyse the affixes (3.3.1), the base (3.3.2) or the status of aspect (3.3.3), each of which will be briefly considered below.

\subsubsection{Affix shapes}

In principle, it is not impossible to reanalyse the existing forms of active adjectives in such a way that they are derived from the root, as presented in (17):

\begin{tabular}{|c|c|c|c|}
\hline Verb & $\begin{array}{l}\text { Verb } \\
\text { root }\end{array}$ & $\begin{array}{l}\text { Potential } \\
\text { adjective }\end{array}$ & Affix involved \\
\hline mol 'praise, I' & mol- & $\begin{array}{l}\text { moltach } \\
\text { 'laudatory' }\end{array}$ & -tach \\
\hline buail 'hit, I' & buail- & $\begin{array}{l}\text { buailteach } \\
\text { 'pugnacious' }\end{array}$ & -teach \\
\hline righneáil 'linger, I' & righneál- & $\begin{array}{l}\text { righneálach } \\
\text { 'lingering' }\end{array}$ & $-a c h$ \\
\hline athraigh 'change, II' & athr- & $\begin{array}{l}\text { athraitheach } \\
\text { 'variant' }\end{array}$ & -aitheach \\
\hline minigh 'explain, II' & min- & $\begin{array}{l}\text { minitheach } \\
\text { 'explanatory' }\end{array}$ & -itheach \\
\hline oscail 'open, II' & oscail- & $\begin{array}{l}\text { oscailteach } \\
\text { 'open, frank' }\end{array}$ & -teach \\
\hline labhair 'speak, II' & labhar- & $\begin{array}{l}\text { labharthach } \\
\text { 'talkative' }\end{array}$ & -thach \\
\hline
\end{tabular}

This move, however, necessitates the proliferation of allomorphs whose distribution is contingent on a number of factors: the conjugation class of the base and its phonological properties (the number of syllables, the palatalised/ non-palatalised nature of the final consonant, whether or not the final consonant is a sonorant, and whether or not the base terminates in -áil). First conjugation verbs which terminate in -áil will form the corresponding potential adjective with -ach. The remaining first conjugation verbs will take either-teach or -tach, depending on whether the root ends in a palatalised 
or non-palatalised consonant respectively. ${ }^{16}$ Second conjugation verbs ending in a sonorant will take -teach or -thach, and otherwise -itheach or -aitheach depending on the palatalised or non-palatalised quality of the final consonant in the root.

The application of a similar procedure to the formation of passive potential adjectives yields the formal markers listed in (18) below:

\begin{tabular}{|c|c|c|c|c|}
\hline & Verb & $\begin{array}{l}\text { Verb } \\
\text { root }\end{array}$ & $\begin{array}{l}\text { Passive potential } \\
\text { adjective }\end{array}$ & $\begin{array}{l}\text { Affixes } \\
\text { involved }\end{array}$ \\
\hline a. & mol 'praise, I' & mol- & $\begin{array}{l}\text { inmholta } \\
\text { 'commendable' }\end{array}$ & $i n--t a$ \\
\hline & buail 'hit, I' & buail- & $\begin{array}{l}\text { sobhuailte } \\
\text { 'vulnerable' }\end{array}$ & so- -te \\
\hline b. & tástáil 'test, I' & tástál- & intástáilte & in- $\mathbf{P}_{\text {te }}$ \\
\hline c. & athraigh 'change, II' & athr- & $\begin{array}{l}\text { so-athraithe } \\
\text { 'adjustable' }\end{array}$ & so- -aithe \\
\hline & minigh 'explain, II' & min- & $\begin{array}{l}\text { somhinithe } \\
\text { 'easily explained' }\end{array}$ & so- -ithe \\
\hline & fuascail 'release, II' & fuascl- & $\begin{array}{l}\text { infhuascailte } \\
\text { 'redeemable' }\end{array}$ & so- -te \\
\hline & labhair 'speak, II' & labhar- & $\begin{array}{l}\text { solabhartha } \\
\text { 'affable' }\end{array}$ & so- -tha \\
\hline
\end{tabular}

Deriving the forms in (18) from the root would entail suffixal-prefixal derivation which is otherwise unattested in Irish. The fact that the morphophonological effects on the right periphery are exactly the same as those observed in the formation of the perfective participle (e.g. the palatalisation of the final consonant in bases terminating in -ál as in (18b)) must be treated as coincidental.

More importantly, by deriving both types of adjectives from the root we fail to capture a semantic generalisation, i.e. the fact that dispositional adjectives have active semantics like the progressive participle, whereas passive potential adjectives have passive semantics like the perfective participle. We also fail to

\footnotetext{
${ }^{16}$ Irish consonants fall into two sets traditionally called "broad" and "slender," which in linguistic terms correspond to non-palatalised and palatalised, respectively. A consonant is, as a rule, broad (non-palatalised) when it precedes or follows one of the back vowels, and slender (palatalised) when it occurs in the environment of a front vowel.
} 
capture a formal generalisation in that we duplicate the operations which must be encoded elsewhere in the MS-component for spelling-out participles.

The analysis sketched above is in line with LMBM, but it is sadly deficient in terms of economy, elegance and semantic relatedness.

\subsubsection{The base is a participle, but aspect is not inflectional}

If we regard participles as stems uninflected for tense and conveying aspect information plus the lexical information of the root (Stump 52), we may consider the option of reanalysing aspect as a lexical feature in Irish. ${ }^{17}$ Participles could then serve as input to further derivation without violating the inflection-derivation split. Cross-linguistically, the category of aspect is relevant to syntax, but it can also be highly relevant to the base meaning (Bybee ch. 4). Its status may vary from language to language and, according to Bybee, it may be expressed lexically, by WF means, inflectionally or at the phrasal level. ${ }^{18}$

This solution, however, must be discarded on theory internal grounds. A form can be regarded as morpholexical in LMBM if it passes three diagnostic tests:

- the Peripheral Affix Test, according to which inflectional marking is outside word formation marking only when it is syntactically engaged (it has an effect on syntactic dependencies such as case, agreement etc.);

- the Arbitrariness Criterion, which says that categories are lexical if they are lexically set to be invariable;

- the Free Analog Test, which says that morpholexical categories are never marked by means of free morphemes cross-linguistically.

The $-t(h) a /-t(h) e$ endings in adjectives are not involved in agreement phenomena, which would explain why they precede derivational markers. Irish has got a large class of aspect invariable verbs which are confined to expressing the progressive aspect (see e.g. Wigger; Bloch-Trojnar, "Derived Imperfectiva Tantum"), which seems to satisfy the Arbitrariness Criterion. However, the third test is not met because aspect is expressed periphrastically in Irish. Inflected forms contrast with the periphrastic progressive construction,

${ }^{17}$ Aspect is understood here as a grammatical category, which expresses the speaker's perspective on a situation, i.e. whether it is viewed as complete (perfective aspect) or ongoing (imperfective aspect) (Comrie). It is not used in the sense of Aktionsart (lexical/semantic aspect), which expresses the intrinsic qualities of a situation (Vendler). In Beard's model, aspect is a morphosyntactic category, and as such cannot be exploited in derivation (cf. footnote 14 above).

${ }^{18}$ For example, Keresan, spoken in New Mexico, and Quilente, spoken in Washington State, express aspect derivationally (Bauer, Introducing). Aspect in Polish can also be argued to be a lexical category (Bloch-Trojnar, "Grammatical Aspect"). 
as in (1b) above, which is viewed as the generalised category of imperfectivity (an introspective aspect) (Ó Corráin; Ó Sé, "Gnáthach"). The perfective participle is used in periphrastic resultative and passive structures, as shown in (19) below (Ó Sé, "The 'After' Perfect" 197; Doyle, "Morphosyntactic Change" 144-46):

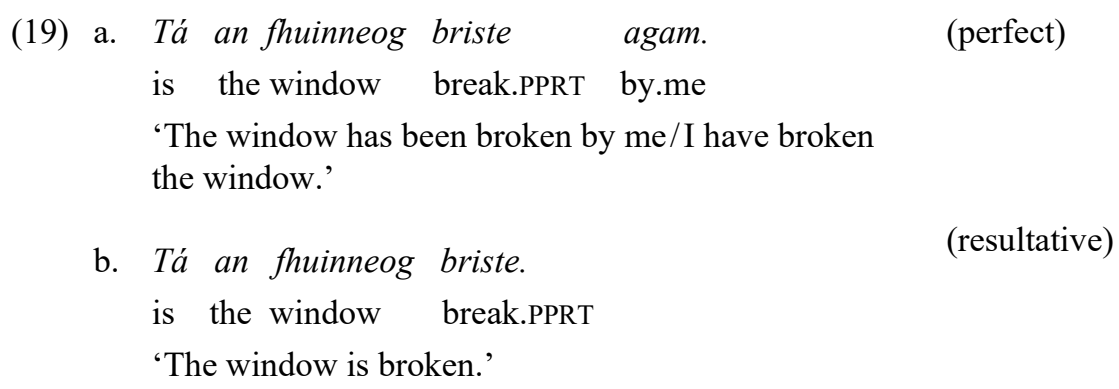

Since grammatical categories marked by free morphemes in syntactic positions must be controlled by syntax, aspect cannot be regarded as a lexical category manipulable by derivation.

\subsubsection{The base is not an aspect-marked form}

For an alternative solution, we may claim that the base for the process is an allomorphic variant of the stem and not a participle. In this way, we get round the problem of prefixal-suffixal modification and the derivation of adjectives is accomplished by one operation-the suffixation of -ach for dispositional adjectives and the prefixation of so-/in- for PPAs. This would imply that there exists in Irish a morphomic function (Aronoff) which supplies a verbal stem in $-t(h) e /-t(h) a$ in an adjectival or adjectivised context. The suffixes would act as stem-extenders, formatives devoid of any semantic content. This solution, however, has the drawback of missing the semantic generalisation concerning the active/passive component of meaning in resulting adjectives.

\subsection{Summary}

The LMBM model can account for the Irish data by deriving the adjectives directly from the root and multiplying formal markers, or by holding down the number of markers and deriving adjectives from a special verbal stem (corresponding to what traditional grammars would call the verbal adjective). 
Both solutions fail to capture the form-meaning correspondence observable between participial morphology and adjective semantics. This effect is only to be expected, since morphemes in LMBM are not linguistic signs and formal markers serve as mere clues rather than determinants of meaning/function.

\section{A DM PERSPECTIVE}

In this section, we shall test the explanatory potential of the constructionist approach, which recognises one generative engine, which is syntax. Section 4.1 lays out the basic assumptions of DM. Since DM is not monolithic, we further specify the particular strain of research within this theoretical paradigm which will be implemented in the following analysis. Section 4.2 presents structures thus far proposed for participles and departicipial adjectives. In section 4.3 we check whether similar structures can be proposed for the Irish data.

\subsection{The basic tenets of the constructionist model}

In the constructionist approach, syntax is responsible for the construction of both words and phrases. The semantics of morphologically complex words is a reflection of their inner structure, which, in turn, is established on the basis of their syntactic behaviour (Halle and Marantz; Marantz; Embick; Alexiadou; Harley and Noyer). Derivation proceeds in cycles which involve the merger of a-categorial roots $(\sqrt{ } \mathrm{s})$ with functional projections (f-morphemes), such as a (for adjectives), $\mathrm{v}$ (for verbs), and $\mathrm{n}$ (for nouns). DM is a realisational framework, in which morphology is a post-syntactic component, distinct from both syntax and phonology, mapping abstract hierarchical morpho-syntactic structures onto linearised phonological structures via Vocabulary Insertion (Halle and Marantz; Marantz; Embick and Noyer). Spell-out proceeds from the earliest merged morpheme (the root) to morphemes which cyclically spell-out the features or heads in the relevant syntactic structure following the phase-based approach to derivation. Morphological markers reflect the projection of relevant layers in the functional sequence, i.e. each morpheme corresponds to a terminal node in the structural analysis in the sentence. Spell-out observes syntactic constituency by default, but may change it. In some cases, a single exponent may realise more than one syntactic head, or sometimes structural positions may be filled with a $\varnothing$ element (Harley, "Morphology"). 
In this paper, I follow the semi-Davidsonian approach as advocated by Alexiadou et al. (External Arguments), who follow Kratzer in severing the external argument from the verb and keeping the internal one as part of the argument structure (AS) of the verb. External arguments are not arguments of verbs but are introduced by the Voice head. Kratzer's VoiceP corresponds to the external argument introducing vP shell in Distributed Morphology (Harley, "Morphology" 325). The presence of the VoiceP in the structure is linked to the ability to take agent-oriented modifiers, $b y$-phrases and instrumental phrases. The internal argument and event implications are associated with the categorizing head $\mathrm{v}$. In the approach adopted here, there is no 'RootP', unlike in the classical DM model (cf. Harley). In this approach, Aktionsart is the domain of the Root-vP complex. The licensing of the internal argument is not contingent on the presence of AspectP (cf. Borer, In Name Only). AspP is above VoiceP and it is associated with aspectual adverbial modification. AspP is projected by verbs which show the perfective-imperfective contrast independently of the inner aspect/Aktionsart. Even higher up is Tense, which is associated with the licensing of temporal and spatial modifiers.

\subsection{Participles and deverbal adjectives in the constructionist approach}

The derived structure is retained in the course of further derivation, and so deverbal adjectives are expected to inherit properties of their verbal bases. Depending on the height of affix attachment in the structure, we can distinguish verbal participles, verbal adjectives and deverbal adjectives (Alexiadou et al., External Arguments; Lundquist). From a cross-linguistic perspective, adjectivised verbal structures can be composed of the root or a verbalised root with an additional vP layer (Anagnostopoulou; Embick) or VoiceP located above vP (McIntyre; Alexiadou and Anagnostopoulou), or a structure with an additional Perfect operator (Alexiadou et al., External Arguments 191). ${ }^{19}$

According to Alexiadou et al. ("The Argument Structure"), verbal and adjectival passives in English and German contain an extra position on top of Voice, i.e. PASS.

\footnotetext{
${ }^{19}$ This structure is applicable to resultant state participles in Greek, Russian, Swedish and other languages "where adjectival passives express the Perfect of Result" (Alexiadou et al., External Arguments 193).
} 
(20)

a.

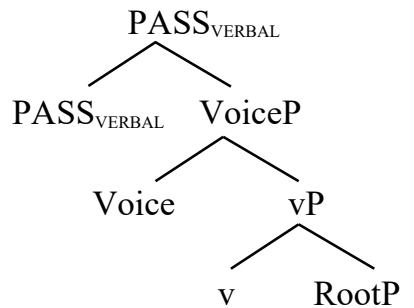

b.

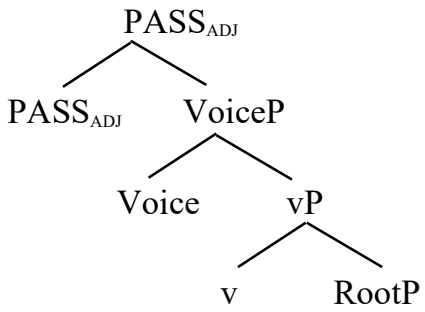

Following Alexiadou et al. (2012), we assume that these heads introduce a Voiceshifting projection. Both PASS-heads select for VoicePs without specifier (see Bruening

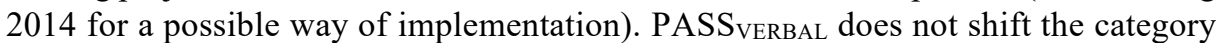
and the event properties, and it basically absorbs the external argument. PASS ADJ $_{\text {Shifts, }}$ in addition, the category and stativises the event (derived stative). (Alexiadou et al., "The Argument Structure" 15) 20

The structures proposed for active adjectives by Sleeman (1579-80) are in agreement with Embick's analysis of the passive participle, in that the participial morphology is introduced in a head Aspect. In her account, fully eventive reduced relatives which take PP complements/objects and can co-occur with eventive modifiers, as in e.g. a singer singing French songs, have the structure in which the lexical root is dominated by vP and AspP (21a). Prenominal present participles not accompanied by adverbs or complements, as in e.g. the singing girl, are argued to contain only a $\mathrm{vP}$ in their structure since they retain an event interpretation (21b). Finally, participles with a stative interpretation, as in e.g. a very astonishing remark, have no vP in their structure, only stative Asp dominating the root, as represented in (21c).

(21)

a.

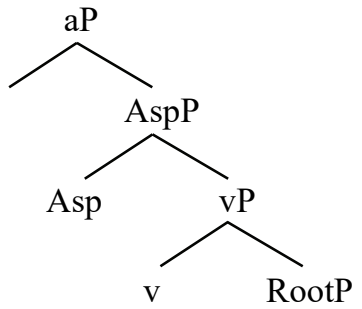

b.

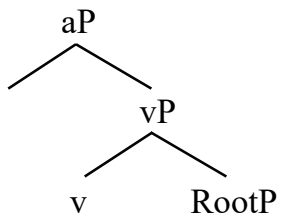

c.

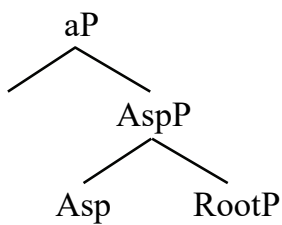

${ }^{20}$ Adjectival passives in German and English allow event-related modification, though restricted to event-kind modification (Gehrke). The licensing of by-phrases, instruments, and agent-oriented adverbs lend support to the presence of VoiceP in their representation. 
In our approach, however, the licensing of eventive modifiers and objects is served by the vP, whereas Asp is located higher up in the structure. Therefore, the structure of the active participle and the departicipial adjective will only contain a Root-vP structure, whereas the aP projection will merge directly with the root in non-eventive (i.e. stative) -ing adjectives.

The height of affix attachment in the structure also has a bearing on the amount of verbal properties preserved in deverbal adjectives. In her analysis of passive potential adjectives in English, Spanish and Catalan, Oltra-Massuet makes a distinction between the high-ble and the low-ble. The regular potential meaning of adjectives with the high-ble follows from the presence of passive and aspectual structures and a modal component in their representation. Adjectives with the low-ble, on the other hand, show heterogenous semantics and idiosyncratic properties due to the fact that functional heads (a stative aspectual head and a modal head) are merged with an uncategorised root. ${ }^{21}$

\section{a. Potential or high -ble} (Oltra-Massuet 151)

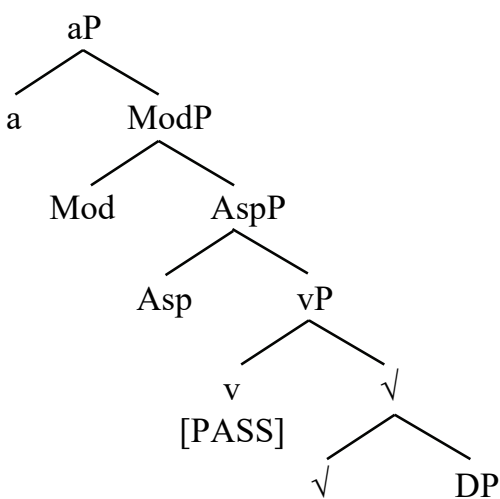

b. Low -ble (Oltra-Massuet 153)

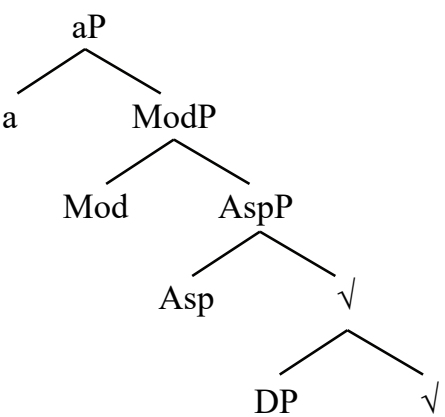

However, it is a matter of some debate whether passive and potential semantics in derived adjectives is a result of the presence of specific functional projections. In contradistinction to neoconstructionist approaches such as Roy and Soare or Oltra-Massuet, the different readings associated with deverbal adjectives (dispositional, potential, episodic) need not follow from the presence of designated (aspectual or modal) projections in the structure of the derived adjective. According to Fábregas ("Deconstructing"), such analyses are flawed since they evoke "null" operators. In his view, the non-episodic reading may

\footnotetext{
${ }^{21}$ Examples of low-ble adjectives include admirable, deplorable, credible, visible.
} 
be the result of the adjectival affix preventing the verb from combining with tense and aspect, or else it is "defined explicitly in the affix, which acts as a function that takes an eventuality and turns it into a set of properties" (Fábregas, "Deconstructing" 34).

In sum: we will assume that the difference between passive and active participles lies in the presence of a transitiviser (Voice) in the former and its absence in the latter. Both contain an eventive verbaliser which triggers event implications. Burzio's constraint formulated for verbal passives also applies inside adjectivisations, in that the theme can be preposed to the specifier of the AP, but not an agent. We can, thus, assume that the active participle-head selects for $\mathrm{vP}$, since in active participles the external role is externalised (whereas in passive participles the internal role is externalised). The modal component (potentiality) in the semantics of deverbal adjectives can be the result of category shift, i.e. the merger with an adjectivising affix results in the verb losing an episodic interpretation. Fábregas ("Deconstructing") maintains that the morphological derivation of adjectives from eventive verbs produces adjectives with non-episodic readings, i.e. readings which do not entail actual participation in a specific event on a particular occasion.

\subsection{The application of the model to the Irish data}

In DM, the presence of particular structural layers is borne out by empirical tests and is reflected in morphological structure which is directly interpretable in semantic terms.

The spell-out of participle morphology can be accompanied by verbalising affixes, which are the spell-out of the $\mathrm{v}$ head, e.g. -ise in colon-is-ed,-ate in dict-at-ed, -ify in html-ifi-ed. In addition, morphological marking present in the causative alternation (e.g. pairs such as sinken-senken 'sink.TRANS/ INTRANS' in German) points to the existence of a Voice layer in the structure (Alexiadou et al., "The Argument Structure"). Distributional properties which point to the presence of the Voice layer in their structure include, amongst others, the ability to take agent-oriented adverbs, $b y$-phrases and instrumental phrases. The presence of $\mathrm{vP}$ in the structure follows from the possibility of manner and event modification.

Before we consider the syntactic behaviour of participles and their corresponding adjectives, a note on the morphological make-up of verbs in Irish is in order. There is morphological evidence supporting the presence of the $\mathrm{v}$ layer responsible for event implications. The verbaliser is overt in 1 st conjugation verbs in -ál, e.g. buama 'bomb'-buamál- 'to bomb' or planda 
'plant' - plandál- 'to plant' (see footnote 10 above). In addition, it has been argued that, since the conjugations are not associated with distinct sets of inflectional exponents (Ó Sé, "Verbal Inflection"), they should be viewed as stem classes rather than inflectional classes, which means that stem types are diacritic features encoded on the $\mathrm{v}$ (Acquaviva 553). There is no morphological indicator of an external argument introducing projection, i.e. the causative/anticausative alternation is not overtly marked in Irish. Furthermore, we are on the right track in assuming that the participial morphology is not the spell-out of the AspP projection, since in available DM accounts of Irish verb morphology aspect is not marked morphologically on the verb. According to Acquaviva, the structure of a finite clause with a lexical verb in Irish contains an AspP located just above vP (corresponding to VoiceP in our approach) and nested in a Tense Phrase (TP). Asp is also the likely locus for preposition-like particles involved in aspectual periphrases, like ag in the progressive (McCloskey, "On the Scope"; Doyle, Covert and Overt Pronominals), illustrated in (1b) above. "The idea that Irish verbal inflection lacks an aspect morpheme also makes it easier to understand why this category finds a periphrastic expression" (Acquaviva 548).

\subsubsection{Eventive and stative passive participles and the passive potential adjective}

The distinction between a statal perfect (resultative) and an actional perfect in Irish is not overtly marked by auxiliaries as is the case in English or German (recall (19a) and (19b) above). Doyle ("Morphosyntactic Change" 146-47) demonstates that the interpretation of a given structure as eventive or resultative depends on the syntactic context. Only the eventive reading is possible in the presence of count adverbials (23a), manner adverbs (23b), frame adverbials (23c) and by-phrases (23d).

(23) a. Tá an teach ceannaithe dhá uair.

is the house buy.PPRT two time

'The house has been bought twice. *The house is bought twice.'

b. Tá an fhuinneog briste go tapaidh.

is the window break.PPRT quick

'The window has been broken quickly. *The window is broken quickly.'

c. Tá 80 saighdiúiri maraithe ó thús na Bealtaine.

are 80 soldiers kill.PPRT since beginning the May.GEN

' 80 soldiers have been killed since the beginning of May.' 
d. Tá teach ceannaithe agam.
is house buy.PPRT at-me

'I have bought a house/A house has been bought by me.'

Interestingly, the structure of (23d) is a passive but its meaning is best rendered by means of an active. These distributional facts confirm Lundquist's (13) observation that a verbal passive participle has the same argument structure and event structure as an active verb, but differs in the way they are realised syntactically (Bruening). The event component in the predicate can license manner, agent and aspectual adverbials.

The addition of a $b y$-phrase points to an eventive interpretation. However, the addition of an adverb of duration will shift it back to resultative (24b), which would point to the presence of the Voice projection in adjectivised participles as well:

(24) a. Tá teach ceannaithe agam.
Is house buy.PPRT at-me

'I have bought a house/A house has been bought by me.'

b. Tá teach ceannaithe agam le dhábhliain.

is house buy.PPRT at-me with two year

'I have a house bought for two years.'

Once the structure is stativised, the adjectival participle refers to a state or a property, just like an adjective. Therefore, adjectival participles (resultative participles) can act as an adnominal modifier (25a) or a complement of the copula (25b):

(25) a. blas dóite

taste burn.PPRT

'burnt taste'

b. Is dóite anblas atá air.

COP burn.PPRT the taste is.REL on-it

'It has a bitter/burnt taste.'

The distributional facts presented above indicate that the structure of the passive participle in Irish is the same as in English/German, as proposed in (20a) above. The PASS-head selects for VoiceP, and does not shift category 
or event properties. Event instantiation is possible when verbal structure is embedded under Tense/Aspect. If the structure is adjoined to the PASS $\mathrm{PDJ}_{\mathrm{A}}$ adjectivising head (or AP in Gehrke), the category changes. Given the fact that the verbal participles can be used like adjectives without any overt marking and allow by-phrase modification, we would like to propose the following structures for cases where only the participle marker is present in the passive/perfective participle and the corresponding adjective:

(26)

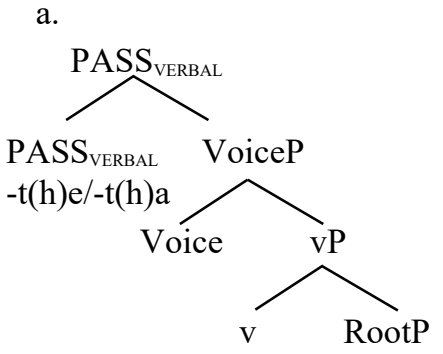

b.

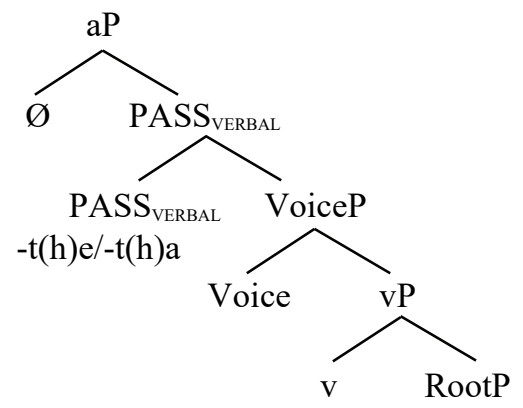

The verbal structure can be adjectivised by means of a zero marker, in which case it merely stativises the event, as shown in (26b) above, or it can be adjectivised by means of an overt affix, leading to the emergence of potential semantics. The prefixes forming PPAs so-/in- can be regarded as the spell-out of the aP projection. In addition to stativity and genericity, they also induce potentiality in the semantic interpretation, as envisaged in the structure for PPAs, shown in (27) below, in which aP dominates PASS, -(t)a/-t(h)e spells out the verbal participle projection and the prefix (in-/so-) acts as the head of aP:

(27)

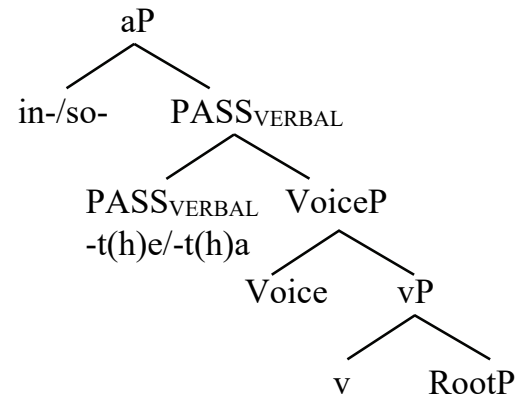


In (28) we present an adjective formed from a verb with an overt verbaliserintástáilte 'testable' - to additionally show that there is a $\mathrm{vP}$ layer in the structure:

(28)

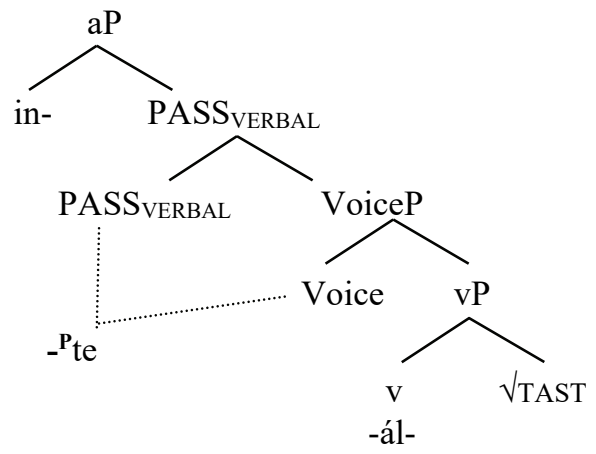

If the structures above are correct, it should not be impossible for passive potential adjectives in Irish to show distributional properties which point to the presence of the Voice layer in their structure. This is indeed the case, as shown in example (29), where the adjective co-occurs with a by-phrase:

(29) Is siombail é an scuadcharr do luachanna údarásacha áirithe atá inaitheanta ag an bpobal mór.

'The squad car is a symbol of certain authoritative values which are recognisable by the general public.'

Control into purpose clauses is another indicator of the presence of the VoiceP projection in the structure, as demonstrated in (30) below:

(30) Ba í an tuairim is tábhachtai a bhí againn ná go raibh sé sodhéanta an scéal a athrú.

'The most important opinion we had was that changing the story was easily done (lit. It was easily done to change the story.)'

Admittedly, passive potential adjectives are not a very productive category in Irish, and contexts in which they are additionally modified are very hard to come by in The New Corpus for Ireland. ${ }^{22}$

\footnotetext{
${ }^{22}$ The New Corpus for Ireland (Nua-Chorpas na hÉireann) contains approximately 30 million words, and is part of the New English-Irish Dictionary project of Foras na Gaeilge.
} 


\subsubsection{Eventive participles and potential adjectives}

In section 4.2 , we concluded that in passive participles the merger with the suffix imposes passive on the structure, which entails covert movement of the theme argument from within the vP to the specifier position and results in agent suppression, which can be optionally realised in VoiceP as an adjunct by-phrase. Furthermore, the adjectivised structure contains two verbal layers (see (20) above). However, the passive component, which is linked with the projection of the external argument, is missing in the structure of the present/progressive participle. Their subject of predication is equated with the subject of the verb. There is only an eventive verbaliser in their structure which triggers event implications (see (21b) above). In adjectivised structures, the noun that the adjectival participles are predicated of is interpreted as the causer or agent of some property (Fábregas, "Adjectival and Adverbial Derivation" 277).

Since both verbal and adjectivised participles contain a vP in their structure, it should be possible for them to license the internal argument. This is possible, but verbal participles have an episodic interpretation, or, to use Gehrke's terminology, they refer to an "event token," i.e. an event that has taken, is taking, or is going to take place in the actual world, and they are obligatorily followed by an object, as shown in (31a) and (31b) below:

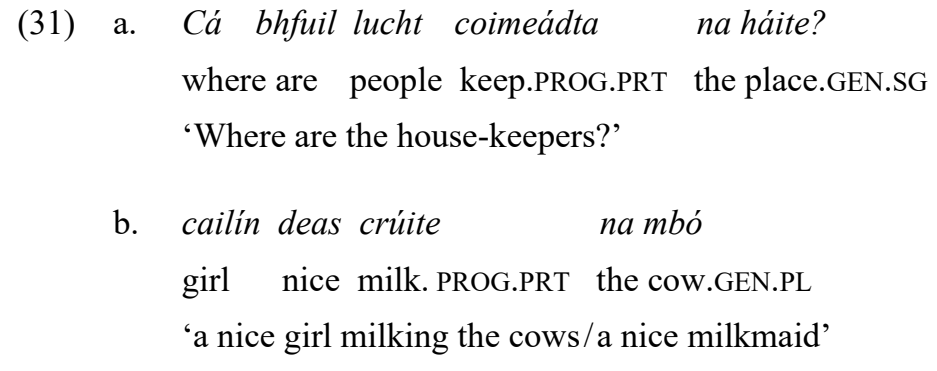

By contrast, adjectivised participles do not have an episodic interpretation pointing to a particular person or people performing a given action at a specific time. They denote "event kinds" (Gehrke) since, if present, the accompanying object is generic. Thus, adjectivised participles are nonepisodic and the presence of the internal argument is optional, as shown in (32) below: ${ }^{23}$

${ }^{23}$ Notably, what we gloss as PROG.PRT and PRT.ADJ, to denote the progressive/present participle and the adjectivised participle respectively, are treated as the genitive case of the verbal noun in traditional grammars. 
(32)
a. gléas maraithe daoine
gléas maraithe
device kill.PRT.ADJ people.GEN.PL
device kill.PRT.ADJ
'a device for killing people'
'leathal weapon'
b. bean chardála olla
woman card.PRT.ADJ wool.GEN.SG
bean chardála
'woman carding wool'
woman card.PRT.ADJ
'carding woman'

Because in (31) the expression of the object is obligatory and the interpretation is episodic, we can assume that we are dealing here with a non-finite verb form which can be treated as the active equivalent of the PASS VERBAL projection, as in (33a) below. Because in (32) the object is not obligatory and the interpretations are non-episodic, we have grounds to assume that the participle structure has been stativised with an aP projection, as shown in (33b).

(33) a.

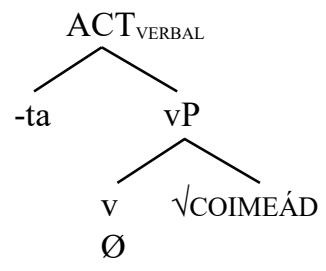

b.

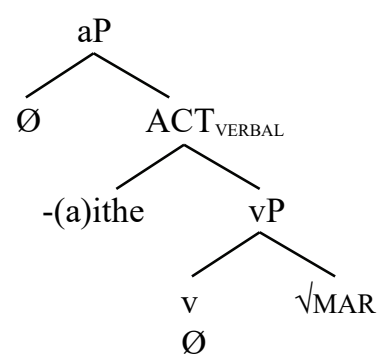

The position of the verbalising head can be overtly realised in the case of participles and adjectivised participles corresponding to verbs in -áil (e.g. cardáil 'card'), i.e. the structure in (34b) is the representation of forms in (32b) above.

(34) a.

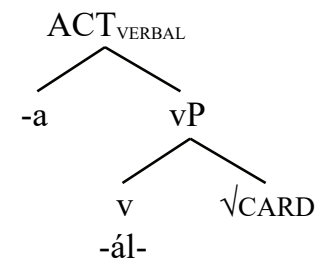

b.

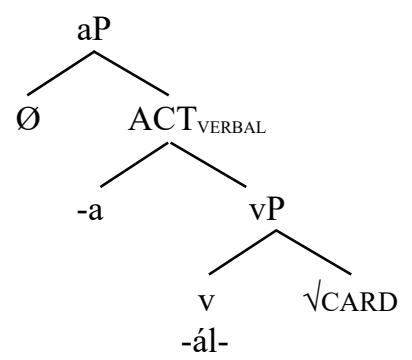


The verbal participle structure (as in (33a) and (34a) above) undergoes further derivation in the formation of active adjectives, which is achieved by introducing an adjectival projection. This projection is spelled out either by a zero exponent (as in (33b) and (34b) above) or the suffix -ach.

Consider the representations of súiteach 'absorbent' and sóinseálach 'changeable, variable' with an overt verbalising affix, and note the correspondence of (35) with (33b) on the one hand and (36) and (34b) on the other:

(35)

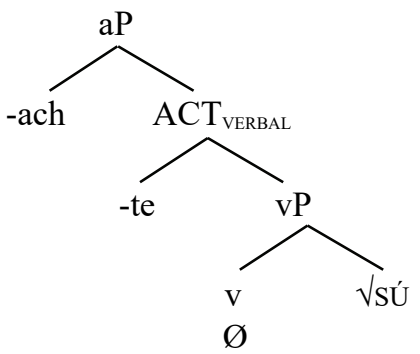

(36)

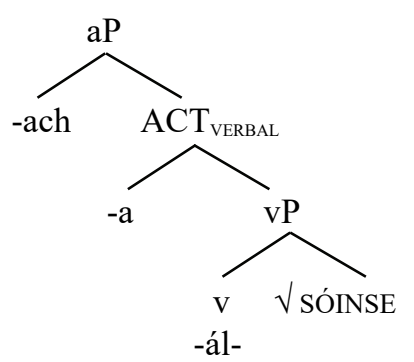

The proposed structures account naturally for the fact that some active participles, in additon to the adjective arising from conversion, have an overtly marked adjectival structure: imir 'play'-imeartha as in lucht imeartha 'players' and imearthach 'playing, tricking; fond of playing, of gambling', súigh 'absorb'—páipéar súite 'blotting paper', súiteach 'absorbent', ardaigh 'raise'—oibreán ardaithe 'raising agent', ardaitheach 'ascendant, ascending'.

In addition, adjectivised participles which are not overtly marked preserve the ability to optionally license the internal argument ${ }^{24}$ and can be perceived as a category which is intermediate between verbal participles and deverbal adjectives in -ach, which stativises the event and blocks the expression of the internal argument.

\section{CONCLUSION}

Deverbal adjectives in Irish belonging to the category of active adjectives bear a formal resemblance to the variant of the active participle used to modify

\footnotetext{
${ }^{24}$ See Cetnarowska ("Departicipial Adjectives") for similar characteristics of adjectivised participles in Polish.
} 
nouns. The base is, for all intents and purposes, a form terminating in $-t(h) a /$ $-t(h) e$ or $-a$. Passive potential adjectives are best accounted for when related to passive participles terminating in $-t(h) a /-t(h) e$. Both the LMBM and the DM model offer theoretical machinery which allows us to handle the data.

In LMBM, which is a lexeme-based model upholding a strict division between lexical and morpho-syntactic phenomena, Irish adjectives cannot be derived from participles. Instead, we can derive them directly from the verbal root or, if we find this account inelegant, we can resort to introducing the notion of a special allomorphic variant of the verbal root which is used in the context of adjectivising morphology. The first solution involves the multiplication of formal markers, the latter misses the formal and semantic relationship between the supposedly 'special' verbal stem and the participle.

In DM, the derived structure is retained in the course of further derivation, and so deverbal adjectives are expected to inherit the properties of their verbal bases and to show adjectival characteristics whose source is the adjectivising projection. The adjective structure can incorporate as much verbal structure as is evidenced by various distributional tests (e.g. Alexiadou et al., "The Argument Structure"). There is no theoretical ban on the use of participles as bases for adjectives and the presence of participles is corroborated by distributional facts. The proposed structures reflect the continuum that can be gleaned from the data and which stretches from verbal participles via adjectivised participles to deverbal adjectives. When the structural aP position is filled with a $\varnothing$ element, we are dealing with an adjective which can still optionally license the internal argument in adjectivised active participles and the external argument in adjectivised passive participles. It behaves like a hybrid category showing verbal and adjectival properties. The proposed representation captures the intuition voiced in traditional grammars that we are dealing here with a verbal adjective (VA). When the adjectiviser is overt, this licensing potential is reduced further.

The constructionist approach provides a simpler and a more perspicuous explanation than its rival. It allows us to capture the fact that different verbal structures are involved in PPAs and active adjectives with different semantic and syntactic effects. In PPAs, the structure licenses the external and the internal argument. In active adjectives, the same marker spells out aP which dominates $\mathrm{vP}$, which results in active semantics. VA morphology merely signals the absence of verbal inflection (Kratzer, Building Statives; Lundquist) and the height of the attachment of the $-t(h) a / t(h) e$ suffix is indicative of what type of participle we are dealing with. LMBM, with its strict separation of 
derivational and inflectional operations, is incapable of establishing the link between the passive and active component in the semantics of adjectives. Active and passive interpretations follow from the semantic effects of the rules of L-derivation (forming Subjective/Active and Objective/Passive adjectives) and any resemblance of the actual formal marking to participles must be viewed as coincidental.

\section{WORKS CITED}

Acquaviva, Paolo. "The Categories of Modern Irish Verbal Inflection." Journal of Linguistics, vol. 50, 2014, pp. 537-586.

Adams, Valerie. Complex Words in English. Longman, 2001.

Alexiadou, Artemis, and Elena Anagnostopoulou. "Structuring Participles." Proceedings of the 26th West Coast Conference on Formal Linguistics, edited by Charles B. Chang and Hannah J. Haynie, Cascadilla Proceedings Project, 2008, pp. 33-41.

Alexiadou, Artemis, Berit Gehrke, and Florian Schäfer. "The Argument Structure of Adjectival Participles Revisited." Lingua, vol. 149, 2014, pp. 118-138.

Alexiadou, Artemis, Elena Anagnostopoulou, and Florian Schäfer. External Arguments in Transitivity Alternations: A Layering Approach. Oxford UP, 2015.

Alexiadou, Artemis, Gianina Iordachioaia, Fabienne Martin, Florian Schäfer, and Mariángeles Cano. “'Direct Participation' and 'Agent Exclusivity' Effects in Derived Nominals and Beyond." Categorization and Category Change in Morphology, edited by Gianina Iordachioaia et al., Cambridge Scholars Publishing, 2012, pp. 155-182.

Alexiadou, Artemis. Functional Structure in Nominals: Nominalization and Ergativity. John Benjamins Publishing Company, 2001

Anagnostopoulou, Elena. "Participles and Voice." Perfect Explorations, edited by Artemis Alexiadou et al., Mouton de Gruyter, 2003, pp. 1-36.

Aronoff, Mark. Morphology by Itself. Stems and Inflectional Classes. MIT Press, 1994.

Bauer, Laurie. English Word Formation. Cambridge UP, 1983.

Bauer, Laurie. Introducing Linguistic Morphology. Edinburgh UP, 1988.

Beard, Robert. Lexeme Morpheme Base Morphology. SUNY Press, 1995.

Bloch-Trojnar, Maria. Polyfunctionality in Morphology. A Study of Verbal Nouns in Modern Irish. Wydawnictwo KUL, 2006.

Bloch-Trojnar, Maria. "Derived Imperfectiva Tantum in Modern Irish." Formal and Historical Approaches to Celtic Languages, edited by Krzysztof Jaskuła, Wydawnictwo KUL, 2011, pp. 83-124.

Bloch-Trojnar, Maria. "Grammatical Aspect and the Lexical Representation of Polish Verbs." Poznań Studies in Contemporary Linguistics, vol. 51, no. 4, 2015, pp. 487-510.

Bloch-Trojnar, Maria. "Constraints on the Derivation of Potential Adjectives in Irish." New Trails and Beaten Paths in Celtic Studies, edited by Maria Bloch-Trojnar et al., Wydawnictwo KUL, 2016, pp. 133-153. 
Bloch-Trojnar, Maria. "A Corpus-Based Perspective on the Formation of Passive Potential Adjectives in Irish.” Journal of Celtic Linguistics, vol. 20, 2019, pp. 1-30.

Bloch-Trojnar, Maria. "Peripheral, Yet in the Centre - A Note on the Use of -ach in Deverbal Adjective Formation in Irish." Centres and Peripheries in Celtic Linguistics, edited by Maria Bloch-Trojnar and Mark Ó Fionnáin, Peter Lang, 2019, pp. 27-43.

Booij, Geert. "Against Split Morphology.” Yearbook of Morphology 1993, edited by Geert Booij and Jaap van Marle, Kluwer Academic Publishers, 1994, pp. 27-50.

Booij, Geert. "Inherent Versus Contextual Inflection and the Split Morphology Hypothesis." Yearbook of Morphology 1995, edited by Geert Booij and Jaap van Marle, Kluwer Academic Publishers, 1996, pp. 1-16.

Borer, Hagit. "V+ing: It Walks Like an Adjective, It Talks Like an Adjective." Linguistic Inquiry, vol. 21, 1990, pp. 95-103.

Borer, Hagit. In Name Only. Structuring Sense. Oxford UP, 2005.

Bresnan, Joan. "The Passive in Lexical Theory.” The Mental Representation of Grammatical Relations, edited by Joan Bresnan, MIT Press, 1982, pp. 3-86.

Bruening, Benjamin. "Word-Formation is Syntactic: Adjectival Passives in English." Natural Language and Linguistic Theory, vol. 32, no. 2, 2014, pp. 363-422.

Burzio, Luigi. Italian Syntax. Reidel, 1986.

Bybee, Joan. Morphology: Typological Studies in Language, vol. 2. John Benjamins Publishing Company, 1985.

Carnie, Andrew. "Mixed Categories in Irish.” Lingua, vol. 121, 2011, pp. 1207-1227.

Cetnarowska, Bożena. "On Inherent Inflection Feeding Derivation in Polish." Yearbook of Morphology 1999, edited by Geert Booij and Jaap van Marle, Kluwer Academic Publishers, 2001, pp. 153-183.

Cetnarowska, Bożena. "Departicipial Adjectives in Polish and English.” Linguistica Silesiana, vol. 28, 2007, pp. 63-79.

Chapman, Carol. "Perceptual Salience and Affix Order: Noun Plurals as Input to Word Formation." Yearbook of Morphology 1995, edited by Geert Booij and Jaap van Marle, Kluwer, 1996, pp.175-184.

Cinque, Guglielmo. "Ergative Adjectives and the Lexicalist Hypothesis." Natural Language and Linguistic Theory, vol. 8, 1990, pp. 1-39.

Comrie, Bernard. Aspect. Cambridge UP, 1976.

de Bhaldraithe, Thomás. Gaeilge Chois Fhairrge: An Deilbhiocht [The Irish of Cois Fhairrge: The Morphology]. Institiúid Ard-Léinn Bhaile Átha Cliath, 1953.

Doyle, Aidan. Noun Derivation in Modern Irish. Selected Categories, Rules and Suffixes. Redakcja Wydawnictw KUL, 1992.

Doyle, Aidan. Irish. Lincom Europa, 2001. Languages of the World/Materials 201.

Doyle, Aidan. Covert and Overt Pronominals in Irish. Folium, 2002.

Doyle, Aidan. "Morphosyntactic Change and the Perfect Passive of Irish." Perspectives on Celtic Languages, edited by Maria Bloch-Trojnar, Wydawnictwo KUL, 2009, pp. 143-160.

Embick, David, and Rolf Noyer. "Distributed Morphology and the Syntax-Morphology Interface." The Oxford Handbook of Linguistic Interfaces, edited by Gillian Ramchand and Charles Reiss, Oxford UP, 2009, pp. 289-324. 
Embick, David. "On the Structure of Resultative Participles in English." Linguistic Inquiry, vol. 35, 2004, pp. 355-392.

Fábregas, Antonio. “Adjectival and Adverbial Derivation.” The Oxford Handbook of Derivational Morphology, edited by Rochelle Lieber and Pavol Štekauer, Oxford UP, 2014, pp. 276-295.

Fábregas, Antonio. "Deconstructing the Non-Episodic Readings of Spanish Deverbal Adjectives." Word Structure, vol. 9, no. 1, 2016, pp. 1-41.

Gehrke, Berit. "Adjectival Participles, Event Kind Modification and Pseudo-Incorporation." Natural Language and Linguistic Theory, vol. 33, 2015, pp. 897-938.

Goldberg, Adele. Constructions: A Construction Grammar Approach to Argument Structure. Cognitive Theory of Language and Culture. U of Chicago P, 1995.

Goldberg, Adele. "Constructions, Lexical Semantics and the Correspondence Principle: Accounting for Generalizations and Subregularities in the Realization of Arguments." The Syntax of Aspect, edited by Nomi Erteschik-Shir and Tova Rapoport, Oxford UP, 2005, pp. 212-236.

Halle, Morris, and Alec Marantz. "Distributed Morphology and the Pieces of Inflection." The View from Building 20: Essays in Honour of Sylvain Bromberger, edited by Ken Hale and Samuel Jay Keyser, MIT Press, 1993, pp. 111-176.

Halle, Morris, and Alec Marantz. "Some Key Features of Distributed Morphology." Papers on Phonology and Morphology. MIT Working Papers in Linguistics 21, edited by Andrew Carnie and Heidi Harley, MIT Press, 1994, pp. 275-288.

Harley, Heidi, and Rolf Noyer. "Licensing in the Non-Lexicalist Lexicon." The Lexicon/ Encyclopaedia Interface, edited by Bert Peeters, Elsevier Press, 2000, pp. 349-374.

Harley, Heidi. "The Morphology of Nominalizations and the Syntax of vP." Quantification, Definiteness and Nominalization, edited by Anastasia Giannakidou and Monika Rathert, Oxford UP, 2009, pp. 321-343.

Harley, Heidi. "On the Identity of Roots.” Theoretical Linguistics, vol. 40, 2014, pp. 225-276.

Hoekstra, Teun. Transitivity. Foris, 1984

Jackendoff, Ray. “Twistin' the Night Away.” Language, vol. 73, 1997, pp. 534-559.

Kratzer, Angelika. "Severing the External Argument from its Verb." Phrase Structure and the Lexicon, edited by Johan Rooryck and Laurie Zaring, Kluwer, 1996, pp. 109-137.

Kratzer, Angelika. Building Statives. U of Massachusetts Amherst, 2000.

Laczkó, Tibor. "Another Look at Participles and Adjectives in the English DP." Proceedings of the LFG01 Conference, edited by Miriam Butt and Tracy Holloway King, CSLI online Publications, 2001. csli-publications.stanford.edu. Accessed 12 March 2019.

Leumann, Manu, J. B. Hofmann, and Anton Szantyr. Lateinische Grammatik auf der Grundlage des Werkes von Friedrich Stolz und Joseph Hermann Schmalz. C. H. Beck, 1963.

Levin, Beth, and Malka Rappaport. "The Formation of Adjectival Passives.” Linguistic Inquiry, vol. 17, 1986, pp. 623-663.

Lundquist, Björn. "The Category of Participles." Categorization and Category Change, edited by Gianina Iordachioaia et al., Cambridge Scholars Publishing, 2013, pp. 11-32.

Marantz, Alec. "No Escape from Syntax: Don't Try Morphological Analysis in the Privacy of Your Own Lexicon." University of Pennsylvania Working Papers in Linguistics, vol. 4, 1997, pp. 201-225.

Markantonatou, Stella. "Modern Greek Deverbal Nominals: An LMT Approach." Journal of Linguistics, vol. 31, 1995, pp. 267-299. 
McCloskey, James. “A VP in a VSO Language?” Order, Concord and Constituency, edited by Gerald Gazdar et al., Foris, 1983, pp. 9-55.

McCloskey, James. "On the Scope of Verb Raising in Irish." Natural Language and Linguistic Theory, vol. 14, 1996, pp. 47-104.

McIntyre, Andrew. "Adjectival Passives and Adjectival Participles in English." Non-Canonical Passives, edited by Artemis Alexiadou and Florian Schäfer, John Benjamins Publishing Company, 2013, pp. 21-42.

Ó Corráin, Ailbhe. "On Verbal Aspect in Irish with Particular Reference to the Progressive." Miscellanea Celtica in Memoriam Heinrich Wagner, Studia Celtica 2, edited by Séamus Mac Mathúna and Ailbhe Ó Corráin, Acta Universitatis Upsaliensis, 1997, pp. 159-172.

Ó Dónaill, Niall. Foclóir Gaeilge-Béarla [Irish-English Dictionary]. An Gúm, 1977.

Ó hAnluain, Liam. Graiméar Gaeilge na mBráithre Críostaí. An Gúm, 1999.

Ó Sé, Diarmuid. "Verbal Inflection in Modern Irish.” Ériu, vol. 42, 1991, pp. 61-81.

Ó Sé, Diarmuid. "Gnáthach agus leanúnach i mbriathar na Gaeilge [Habitual and Progressive in the Irish Verb].” Béalra. Aistí ar theangeolaiocht na Gaeilge [Béalra: Essays on Irish Linguistics], edited by Brían Ó Catháin and Ruairí Ó hUiginn, An Sagart, 2001, pp. 123-145.

Ó Sé, Diarmuid. "The 'After' Perfect and Related Constructions in Gaelic Dialects." Ériu, vol. 54, 2004, pp. 179-248.

Oltra-Massuet, Isabel. Deverbal Adjectives at the Interface: A Crosslinguistic Investigation into the Morphology, Syntax and Semantics of -ble. Mouton de Gruyter, 2013.

Perlmutter, David. "The Split Morphology Hypothesis: Evidence from Yiddish." Theoretical Morphology: Approaches in Modern Linguistics, edited by Michael Hammond and Michael Noonan, Academic Press, 1988, pp. 79-100.

Rainer, Franz. "Inflection Inside Derivation: Evidence from Spanish and Portuguese." Yearbook of Morphology 1995, edited by Geert Booij and Jaap van Marle, Kluwer, 1996, pp. 83-91.

Roy, Isabelle, and Elena Soare. "L'enquêteur, le surveillant et le détenu: les noms déverbaux de participant aux événements, lectures événementielles et structure argumentale." Lexique, vol. 20, 2012, pp. 207-231.

Ruppenhofer, Josef, and Laura A. Michaelis. "A Constructional Account of Genre-Based Argument Omissions." Constructions and Frames, vol. 2, no. 2, 2010, pp. 158-184.

Sleeman, Petra, and Els Verheugd. "Deverbal Adjectivalization as a Gradual Process." Acta Linguistica Hungarica, vol. 47, no. 1-4, 2000, pp. 315-333.

Sleeman, Petra. "Verbal and Adjectival Participles: Internal Structure and Position." Lingua, vol. 121, no. 10,2011 , pp. 1569-1587.

Stump, Gregory. "Word-Formation and Inflectional Morphology." Handbook of Word-Formation, edited by Pavol Štekauer and Rochelle Lieber, Springer, 2005, pp. 49-71.

Sullivan, Thelma. Compendio de la Gramática Náhuatl. Universidad Nacional Autónoma de México, 1983.

Szymanek, Bogdan. Categories and Categorisation in Morphology. Redakcja Wydawnictw KUL, 1988.

Vendler, Zeno. Linguistics in Philosophy. Cornell UP, 1967.

Wasow, Thomas. "Transformations and the Lexicon." Formal Syntax, edited by Peter W. Culicover et al., Academic Press, 1977, pp. 327-360. 
Wigger, Arndt. "Preliminaries to a Generative Morphology of the Modern Irish Verb." Ériu, vol. 23, 1972, pp. 162-213.

Wunderlich, Dieter. "Partizipien in Deutsch.” Linguistische Berichte, vol. 111, 1987, pp. 345-417.

\section{W POSZUKIWANIU MODELU DERYWACJI ODIMIESŁOWOWYCH PRZYMIOTNIKÓW SKŁONNOŚCIOWYCH ORAZ POTENCJALNYCH W JĘZYKU IRLANDZKIM}

\section{Streszczenie}

Artykuł bada potencjał wyjaśniający dwóch separacyjnych modeli opisu językowego, tj. leksykalistycznego modelu LMBM (Lexeme Morpheme Base Morphology) oraz modelu DM (Morfologii Rozproszonej - Distributed Morphology), na podstawie analizy odimiesłowowych przymiotników skłonnościowych i potencjalnych w języku irlandzkim, które tworzy się za pomocą niezerowych wykładników morfologicznych. W modelu LMBM, w którym zjawiska leksykalne i morfo-syntaktyczne są rozdzielone, irlandzkie przymiotniki muszą być derywowane bezpośrednio od rdzenia czasownikowego lub specjalnego allomorfu rdzeniowego używanego w kontekście adjektywizacji. Pierwsze rozwiązanie pociąga za sobą zwiększenie ilości wykładników formalnych, drugie nie jest w stanie uchwycić formalnego i semantycznego związku pomiędzy 'specjalnym' allomorfem rdzeniowym a imiesłowem. Morfologia Rozproszona wypada lepiej, gdyż teoria ta nie nakłada ograniczeń na występowanie form fleksyjnych w strukturach przymiotnikowych. Ponadto obecność imiesłowów w strukturach przymiotnikowych znajduje potwierdzenie w testach dystrybucyjnych. Struktury te tworzą kontinuum: imiesłów - przymiotnik odimiesłowowy - przymiotnik odczasownikowy.

Słowa kluczowe: fleksja inherentna; przymiotnik odimiesłowowy; przymiotnik skłonnościowy; przymiotnik potencjalny; LMBM; Morfologia Rozproszona; język irlandzki. 